\title{
PENGARUH AIR REBUSAN DAUN HARENDONG BULU (Clidemia hirta) TERHADAP KADAR GULA DARAH MENCIT (Mus musculus)
}

\author{
Okta Malia ${ }^{*}$, Dian Samitra ${ }^{2}$, Eka Lokaria ${ }^{3}$ \\ 1,2,3STKIP PGRI Lubuklinggau, Jl. Mayor Toha Kel Air Kuti Kota Lubuklinggau 31626, \\ Indonesia \\ *Corresponding author, e-mail: okta05861@gmail.com
}

\begin{abstract}
This study aims to determine the effect of the water boiled leaves of Clidemia hirta on blood sugar levels in Swiss Webster mice (Mus musculus). This research using a completely randomized design research design (CRD) with 5 treatment groups namely; Aquades control group (P0), 3 g sucrose treatment (P1), 3 g sucrose treatment + boiled bristle leaves boiled water at a dose of $0.13 \mathrm{ml} / \mathrm{KgBB}(\mathrm{P} 2), 3 \mathrm{~g}$ sucrose treatment + boiled bristle leaves boiled water at a dose of $0.26 \mathrm{ml} / \mathrm{KgBB}$ (P3), $3 \mathrm{~g}$ treatment of sucrose + boiled bristle leaves boiled water at a dose of $0.39 \mathrm{ml} / \mathrm{KgBB}$ (P4). Before administration of the extract, mice in the treatment groups P1, P2, P3 \& P4 were induced using $3 \mathrm{~g}$ of sucrose for 5 days. Then after 5 days for groups P2, P3, and P4 followed by giving boiled water leaves for 7 days. The analysis result of One Way Anova Test shows that $\mathrm{F}_{\text {count }}>$ $\mathrm{F}_{\text {table }}(18.86>2.51)$. This shows the boiled water affects the blood sugar levels of male Swiss Webster mice. The concentration of extract at P4 $(0.39 \mathrm{ml} / \mathrm{KgBB})$ was more effective in reducing blood sugar levels.
\end{abstract}

Keywords: Boiled Water, Blood Sugar Levels, Swiss Webster Mice

\section{PENDAHULUAN}

Gaya hidup yang pasif serta pola makan yang tidak teratur dan tidak sesuai dengan kebutuhan tubuh dapat menjadi pemicu peningkatan obesitas (Kelebihan berat bedan) dan diabetes mellitus (Umar, dkk. 2013). Diabetes Mellitus (DM) merupakan penyakit kronis, yang terjadi ketika pankreas tidak memproduksi insulin yang cukup, atau ketika tubuh tidak dapat secara efektif menggunakan insulin yang dihasilkan, hal ini menyebabkan peningkatan konsentrasi glukosa darah (WHO, 2014).

Kadar gula yang tinggi dan tidak terkendali karena diabetes dapat menyebabkan kerusakan sistematik dalam tubuh (Kartini, dkk., 2015). Pasien diabetes mellitus yang tidak diobati akan menyebabkan koma karena $\mathrm{pH}$ darah turun dan terjadinya dehidrasi (Harti, 2014). Data yang didapat pada tahun 2015 diabetes mellitus menjadi ancaman yang serius bagi manusia dan telah menjadi penyebab kematian terbanyak yakni peringkat ke-4 dengan jumlah penyandang diabetes mellitus terbanyak di dunia setelah Amerika Serikat, India, dan China (Kartini, dkk., 2015).

Penyakit diabetes mellitus banyak menyebabkan kamatian sehingga dikembangkan obat alami yang menurunkan kadar glukosa darah dalam tubuh. Pengobatan herbal untuk mengobati penyakit telah dikenal di daerah Asia dan negara-negara berkembang termasuk Indonesia, yang penduduknya sering menggunakan obat-obatan tradisional disebabkan harganya lebih murah dan lebih aman daripada obat sintesis (Kartini, dkk., 2015). Masyarakat juga meyakini 
pengobatan dengan tanaman obat lebih baik dibandingkan harus mengkonsumsi obat kimia yang di khawatirkan akan menimbulkan efek samping yang tidak diinginkan (Makalalag, dkk. 2013).

Hasil penelitian yang telah dilakukan oleh Shinta \& Sudyanto (2016) Air rebusan daun sirih merah (Piper crocatum Ruiz \& Pav) berpengaruh menurunkan kadar glukosa darah mencit putih jantan. Hal ini dikarenakan kandungan didalam air rebusan daun sirih merah terdapat senyawa flavonoid \& tanin. Flavonoid dalam mekanisme penurunan kadar gula darah menghambat aktivitas enzim a-glukosidase (Mataputun, dkk., 2013) dan meregenerasi sel ß-pankreas serta membantu merangsang sekresi insulin (Dheer \& Bhatnagar, 2010). Mekanisme tanin sebagai antidiabetik terdapat beberapa mekanisme yaitu menghambat penyerapan glukosa diintestinal dan menghambat adipogenesis (Kumari \& Jain, 2012).

Beberapa tanaman yang mampu menghasilkan zat alami berupa flavonoid yaitu harendong bulu (Clidemia hirta). Hasil skrining fitokimia daun harendong bulu mengandung senyawa metabolit sekunder dengan konsentrasi tertinggi +5 yaitu tanin dan flavonoid (Afifuddin, dkk., 2015). Flavonoid dan tanin memiliki aktivitas penurunan kadar glukosa darah dengan cara menghambat kerja a-glukosidase (Yuda, dkk., 2015). Mekanisme penyembuhan penyakit diabetes, flavonoid diduga berperan secara signifikan meningkatkan aktivitas enzim antioksidan dan mampu meregenerasi sel-sel ß-pankreas yang rusak sehingga defesiensi insulin dapat diatasi. Flavonoid yang terkandung di dalam tumbuhan diduga juga dapat memperbaiki sensitifitas reseptor insulin (Marianne, dkk., 2011). Mekanisme tanin sebagai antidiabetik terdapat beberapa mekanisme yaitu menghambat penyerapan glukosa di intestinal dan menghambat adipogenesis. Selain itu tanin bertindak sebagai pemangsa radikal bebas dan mengaktifkan enzim antioksidan (Kumari \& Jain, 2012).

Penelitian ini bertujuan untuk mengetahui pengaruh air rebusan daun harendong bulu (Clidemia hirta) terhadap kadar gula darah pada mencit (Mus musculus).

\section{METODE}

Penelitian dilaksanakan di Laboratorium Biologi STKIP-PGRI Lubuklinggau pada bulan Mei-Juni 2020. Alat dan bahan yang digunakan dalam penelitian ini berupa kandang mencit, timbangan analitik, nampan, wadah makan mencit, botol minun mencit, ember, kamera, gavage, Syiringe $1 \mathrm{ml}$, glukosa test (merk Nesco), strip glukosa, sarung tangan, tisu gulung, toples, pipet tetes, gunting, air rebusan daun harendong bulu, mencit jantan galur Swiss webster, pakan mencit, sekam padi, larutan sukrosa, aquades, betadine/alkohol, dan kapas.

1. Penyediaan mencit dan pembagian kelompok perlakuan

Mencit (Mus musculus) jantan ini didapatkan dari peternak yang berada di Kota Palembang. Mencit dimasukkan kedalam kandang agar dapat beradaptasi terhadap lingkungannya. Proses adaptasi ini memerlukan waktu \pm 1 minggu untuk dapat mengenal tempat tinggal baru, serta lingkungan sekitar dengan diberikan pakan dan minum.

Mencit dikelompokkan secara acak menjadi 5 kelompok perlakuan dengan masing-masing kelompok dengan masing-masing 5 kali perlakuan. Mencit diinduksi larutan sukrosa $3 \mathrm{~g} / \mathrm{kg}$ bb 1 kali sehari selama 5 hari berturut-turut dipagi hari (Saputra, dkk., 2018), secara jelas dan lengkap dapat dilihat pada Tabel 1. 
Tabel 1. Pengelompokan Mencit (Mus musculus) Jantan Berdasarkan Perlakuan dan Dosis yang digunakan.

\begin{tabular}{cccc}
\hline No & $\begin{array}{c}\text { Kelompok } \\
\text { Perlakuan }\end{array}$ & Dosis Perlakuan & $\begin{array}{c}\text { Jumlah } \\
\text { Pengulangan }\end{array}$ \\
\hline 1 & P0 & Kontrol (-) Aquades & 5 \\
2 & P1 & 3 g/kgBB Sukrosa & 5 \\
3 & P2 & Sukrosa + 0,13 ml Air Rebusan & 5 \\
4 & P3 & Sukrosa + 0,26 ml Air Rebusan & 5 \\
5 & P4 & Sukrosa + 0,39 ml Air Rebusan & 5 \\
\hline
\end{tabular}

2. Pembuatan air rebusan daun harendong bulu

Pertama daun harendong bulu (Clidemia hirta) dicuci bersih dengan air mengalir untuk memisahkan kotoran dan bahan-bahan asing dari daun. Setelah kering, iris kecil-kecil kemudian rebus daun harendong bulu sebanyak $200 \mathrm{~g}$ dengan menggunakan air sebanyak $200 \mathrm{ml}$, selanjutnya rebus daun harendong bulu dengan suhu sekitar $90^{\circ} \mathrm{C}$ selama kurang lebih 15 menit (Shinta \& Sudyanto, 2016).

3. Pemberian perlakuan

Sebelum pemberian air rebusan daun harendong bulu, mencit pada kelompok P1, P2, P3 dan P4 terlebih dahulu diberikan Larutan sukrosa yang diambil sebanyak 3 $\mathrm{gr} / \mathrm{kg}$ bb mencit dan dilarutkan dalam aquades sebanyak 0,5 ml (Mokuna, dkk., 2014). Setelah diberikan larutan sukrosa 3 gr mencit pada kelompok P2, P3 dan P4 diberikan air rebusan daun harendong bulu (Clidemia hirta) sebanyak dosis yang dibutuhkan menggunakan jarum gavage. Dosis yang telah diambil, kemudian di masukkan ke dalam mulut mencit menggunakan jarum gavage. Rebusan daun harendong bulu diberikan 1 kali sehari pada pagi hari selama 7 hari (Herlina, 2017).

Dosis perlakuan air rebusan Clidemia hirta yang digunakan terdiri kelompok P0: Aquades, P1: 3 gr/kgBB Sukrosa, P2: 3 gr/kgBB sukrosa + 0,13 ml /BB air rebusan daun harendong bulu, P4: $3 \mathrm{gr} / \mathrm{kgBB}$ sukrosa $+0,26 \mathrm{ml} / \mathrm{BB}$ air rebusan daun harendong bulu, P4: $3 \mathrm{gr} / \mathrm{kgBB}$ sukrosa $+0,39 \mathrm{ml} / \mathrm{BB}$ air rebusan daun harendong bulu (Shinta \& Sudyanto, 2016).

4. Analisis data

Uji prasyarat yang digunakan yaitu uji normalitas dengan uji Liliefors, uji homogenitas dengan uji barlet dan dilanjutkan dengan uji Anava satu jalur.

\section{HASIL DAN PEMBAHASAN}

Berdasarkan hasil penelitian dan perhitungan, data normal Lhitung $<$ Ltabel $(0,1484$ $<0,18)$, Uji homogenitas $\mathrm{X}^{2}$ hitung $>\mathrm{X}^{2}$ tabel $(34,84>9,488)$. Karena hasil analisis statistik menunjukkan data normal dan homogen, maka analisis statistik dilanjutkan dengan uji Anava satu jalur $F_{\text {hitung }}>F_{\text {tabel }}(18,86>2,51)$. Hasil rekapitulasi pengukuran kadar gula pada penelitian ini dapat dilihat pada Tabel 2. Penurunan kadar gula pada mencit sebelum dan sesudah perlakuan dengan air rebusaan daun harendong bulu dapat dilihat pada Gambar 1.

Setelah dilakukan penelitian mengenai pengaruh air rebusan daun harendong bulu terhadap kadar gula darah mencit selama 7 hari, maka didapatkan hasil data setelah di uji dengan menggunakan Uji Normalitas dengan Lilliefors, ketentuan Lhitung $<$ Ltabel dengan nilai Lhitung $=0,1484$ dan Ltabel $=0,18$ maka Ho diterima dan dapat disimpulkan bahwa data berdistribusi nornal. Uji Homogenitas dengan Uji Barlett didapat bahwa data homogen, karena $\mathrm{X}^{2}$ hitung $>\mathrm{X}^{2}$ tabel $(34,84>9,488)$ dengan taraf 0,05, sehingga Ho ditolak dan dapat disimpulkan bahwa kelima kelompok data 
tersebut memiliki varian yang sama/homogen. Data homogen dilanjutkan dengan analisis varian satu jalur, berdasarkan hasil analisis statistik menunjukkan hasil yang signifikan, ada satu kelompok yang mengalami penurunan glukosa yang siginifikan yaitu pada kelompok P4 dengan dosis 0,39 ml air rebusan daun harendong bulu. Dapat diasumsikan pula bahwa pada kelompok P4 memiliki jumlah dosis yang besar dibandingkan kelompok P1, P2, dan P3, sehingga flavonoid yang dihasilkan dalam jumlah yang banyak (Studiawan \& Santoso, 2005).

Tabel 2. Rekapitulasi Hasil Pengukuran Kadar Gula pada Mencit Setelah diberikan Perlakuan.

\begin{tabular}{ccc}
\hline No & Perlakuan & Rata-rata Kadar gula \pm SD (mg/dl) \\
\hline 1 & P0 (-) Aquades & $110,6 \pm 9,12$ \\
2 & P1 (+) (Sukrosaa) & $150,2 \pm 4,49$ \\
3 & P2 (Sukrosa + 0,13 air rebusan) & $134,4 \pm 11,92$ \\
4 & P3 (Sukrosa + 0,26 air rebusan) & $118,8 \pm 8,04$ \\
5 & P4 (Sukrosa + 0,39 air rebusan) & $113,8 \pm 7,19$ \\
\hline
\end{tabular}

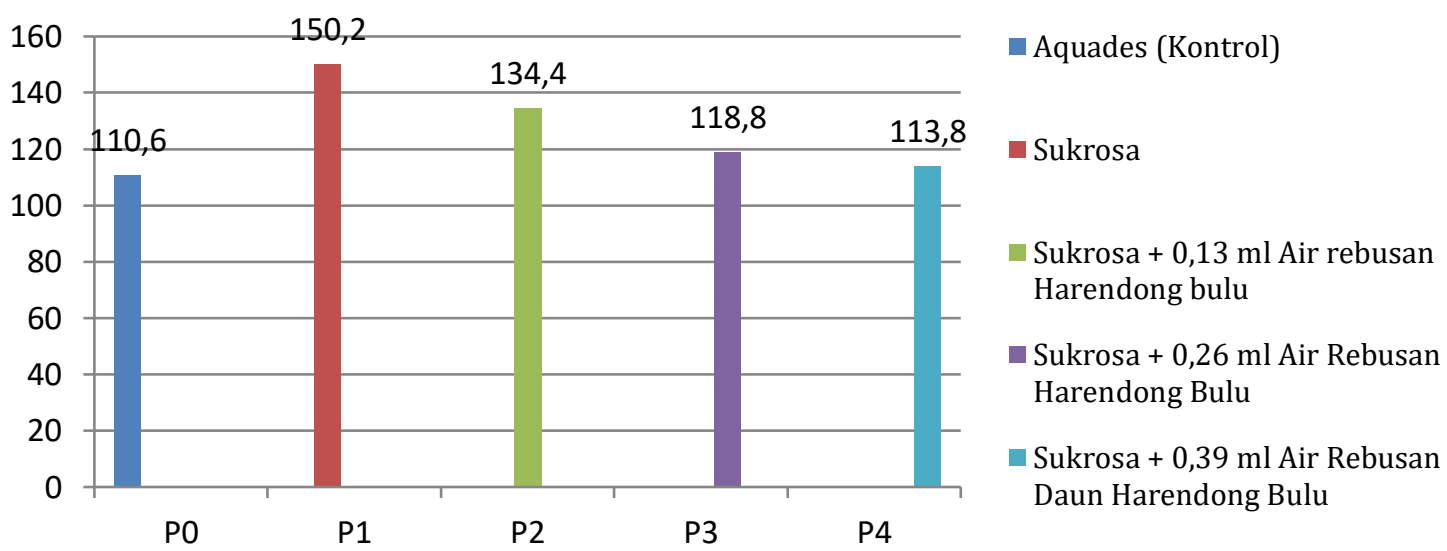

Gambar 1. Rata-Rata Penurunan Kadar Gula Darah Mencit (Mus musculus)

Berdasarkan hasil analisis menunjukkan bahwa kelompok P0 dengan perlakuan kontrol aquades digunakan sebagai perbandingan P1 yang diinduksi dengan sukrosa mengalami peningkatan kadar gula darah yaitu dari 110,6 mg/dl menjadi 150,2 $\mathrm{mg} / \mathrm{dl}$, lalu pada kelompok perlakuan P2, P3, dan P4 terlihat bahwa air rebusan daun harendong bulu dapat menurunkan kadar gula darah mencit dari rerata $134,4 \mathrm{mg} / \mathrm{dl}$, $118,8 \mathrm{mg} / \mathrm{dl}$ sampai 113,8 $\mathrm{mg} / \mathrm{dl}$ dan telah dibuktikan dengan uji beda BNT dengan kriteria nilai KK sedang 6,78\% dan didapatkan hasil kelompok P1 berbeda nyata dengan kelompok P4, kelompok P1 notasinya "a" dan kelompok P4 notasinya "d". Penurunan kadar gula darah mencit dapat diakibatkan karena adanya kandungan flavonoid dan tanin di dalam air rebusan daun harendong bulu.

Pada penelitian ini digunakan sampel berupa daun harendong bulu (Clidemia hirta) yang direbus $90^{\circ} \mathrm{C}$ selama kurang lebih 15 menit. Sebelum proses perebusan daun harendong bulu terlebih dahulu diiris kecil-kecil kemudian rebus daun harendong bulu sebanyak 200 gram dengan menggunakan air sebanyak $200 \mathrm{ml}$ (Shinta \& Sudyanto, 2016).

Hewan uji yang digunakan adalah 25 ekor mencit yang dibagi menjadi 5 kelompok perlakuan. Dalam perlakuan ini, dosis air rebusan daun harendong bulu yang digunakan disesuaikan dosis untuk manusia yang telah dikonversikan. Setelah dikonversikan didapatkan dosis 0,13 ml untuk P2, 0,26 ml untuk P3, dan 0,39 ml untuk P4. 
Berdasarkan hasil skrining fitokimia daun harendong bulu mengandung senyawa metabolit sekunder dengan konsentrasi yang tinggi yaitu tanin dan flavonoid (Afifuddin, dkk, 2015). Flavonoid dan tanin memiliki aktivitas penurunan glukosa darah dengan cara menghambat kerja a-glukosidase sehingga penyerapan glukosa dan laju peningkatan gula pada sistem pencernaan masih tidak terlalu tinggi. Senyawa antidiabetik ini menyebabkan flavonoid dan tanin memiliki peran penting dalam pencegahan dan pengobatan beberapa penyakit salah satunya adalah diabetes (Yuda, dkk., 2015). Adanya inhibitor glukosidase yang merupakan agen potensial terapi diabetes sehingga glukosidase dapat mempengaruhi mekanisme biologis dengan baik dan efektif (Pereira, dkk., 2011). Sehingga adanya flavonoid dan tanin memberikan efek yang menguntungkan pada keadaan diabetes (Yuda, dkk., 2015). Pada penelitian Ekstrak etanol daun Etlingera hemisphaerica yang mengandung flavonoid pada dosis yang sama yaitu $0,39 \mathrm{mg} / \mathrm{g}$ bb berpotensi menurunkan kadar glukosa darah $(36,2 \%)$ pada Mus musculus yang disertai hiperglikemia (Ruyani, dkk., 2014).

Flavonoid menghambat aktivitas enzim a-glukosidase (Mataputun, dkk., 2013) dan meregenerasi sel $ß$-pankreas serta membantu merangsang sekresi insulin (Dheer \& Bhatnagar, 2010). Flavonoid dapat menghambat kerusakan sel $ß$ pada pulau langerhans pankreas yang menghasilkan insulin dan merangsang pelepasan insulin pada sel $ß$ pangkreas untuk disekresikan ke dalam darah, selain itu flavonoid juga dapat mengembalikan sensitivitas reseptor insulin pada sel (Atiqoh, dkk., 2017). Mekanisme tanin sebagai antidiabetik terdapat beberapa mekanisme yaitu menghambat penyerapan glukosa diintestinal dan menghambat adipogenesis (Kumari \& Jain, 2012).

\section{SIMPULAN}

Berdasarkan hasil penelitian yang telah dilakukan, mengenai pengaruh air rebusan daun harendong bulu terhadap kadar gula darah pada mencit yang telah di uji dengan hasil uji analisis varian satu jalur didapatkan data $F_{\text {hitung }}>F_{\text {tabel }} \quad(18,86>$ 2,51) dan dapat disimpulkan bahwa air rebusan daun harendong bulu (Clidemia hirta) berpengaruh terhadap kadar gula darah pada mencit.

\section{REFERENSI}

Afifuddin, Y., Marpaung, L., \& Silitonga, Y. (2015) Eksploitasi Tumbuhan Beracun di Cagar Alam Martelu Silitonga. Skripsi. Fakultas Pertanian Universitas Sumatera Utara.

Atiqoh, H., Wardani, S.R \& Meikawati, W. (2011). Uji Antidiabetik Infusa Kelopak Bunga Rosella (Hibiscus sabdariffa Linn) Pada Tikus Jantan Galur Wistar yang di Induksi Glukosa. Jurnal Kesehatan Masyarakat Indonesia, 7(1), 43-50.

Dheer, R \& Bhatnagar, P. (2010). A Study of Antidiabetic Activity of Barleria prionitis Linn. Indian Jurnal of Pharmacology, 42(2), 70-73.

Harti, A.S. (2014). Biokimia Kesehatan. Yogyakarta: Nuha Medika.

Herlina, Y. (2017). Pengaruh Air Rebusan Daun Supit Kijang (Tetracera indica) Terhadap Kadar Gula Darah Mencit Swiss webster jantan. Skripsi. Pendidikan Biologi, STKIP PGRI Lubuklinggau.

Kartini, K., Swantara, I \& Suartha, Y.I. (2015). Isolasi dan Identifikasi SenyawaAktif Ekstrak Etanol Buah Pare (Momordica charantia) yang Dapat Menurunkan Kadar Glukosa Darah. Cakra Kimia (Indonesia E-Journal of Appled Chemistry)., 3(12), 32-38. 
Kumari, M \& Jain, S. (2012). Tanins: An Antinutrient with Positive Effect to Manage Diabetes. Research Journal of Recent Science, 1(12), 70-1.

Makalalag, I.W., Wullur, A., \& Wiyono, W., (2013). Uji Ekstrak Daun Binahong (Anredera cordifolia) Terhadap Kadar Gula Darah Pada Tikus Putih Jantan Galur Wistar (Rattus norvegicus) Yang Diinduksi Sukrosa. PHARMACO Jurnal Ilmiah Farmasi-UNSRAT, 2(01), 2302-2493.

Mataputun, P.S., Rorong, A.J \& Pontoh, J. (2013). Aktivitas Inhibitor a-Glukosidase Ekstrak Kulit Batang Matoa (Pometia pinnata) Sebagai Agen Antihiperglikemik. Jurnal MIPA UNSRAT, 2(2), 119-123.

Mokuna, N., R. Pitopang, \& Yuliet. (2014). Uji Efek Antidiabetes Ekstrak Akar Garcinia rostrata Hassk.ex Hook.f Pada Mencit Jantan (Mus musculus) dengan Metode Toleransi Glukosa dan Induksi Aloksan. Biocelebes, 8(2), 37-47.

Pereira, D.F., Cazarolli, H.L, Lavado, C., Mengatto, V., Figueiredo, B., Guedes, A., Pizzolatti, G.M \& Silva, B.M.R.F. (2011). Effects of Flavonoids on $\alpha$-glucosidase Activity: Potential Targets for Glucose Homeostasis. Nutrition, 27(12), 11611167.

Ruyani, A., Sundaryono, A., Rozi, F. Z., Samitra, D., \& Gresnita, E. (2014). Potential Assessment Of Leaf Ethanolic Extract Honje (Etlingera hemisphaerica) in Regulating Glucose and Triglycerides On Mice (Mus musculus). International Journal of Science, 3(1), 71-76.

Saputra, R. M., Yuniarti, E \& Sumarni, R. (2018). Pengaruh Ekstrak Daun Sirih Merah (Piper crocatum Ruiz \& Pav.) Terhadap Glukosa Darah Mencit (Mus musculus L.) Jantan yang Diinduksi Sukrosa. Eksakta, 19(1), 43-55.

Shinta, Y.D \& Sudyanto. (2016). Pemberian Air Rebusan Daun Sirih Merah (Piper crocatum) Terhadap Kadar Glukosa dan Kolesterol Darah Mencit Putih Jantan. Sainstek: Jurnal Sains dan Teknologi, 8(2), 180-185.

Studiawan, H \& Santoso, H.M. (2005). Uji Aktivitas Penurunan Kadar Glukosa Darah Ekstrak Daun Eugenia polyantha pada Mencit yang di Induksi Aloksan. Jurnal Media Kedokteran Hewan, 21(2), 62-65.

Umar, A., Bodh, W \& Kepel, J.B. (2013). Gambaran Gula Darah pada Remaja Obes di Minahasa. Jurnal e-Biomedik (eBM), 1(1), 265-269.

WHO. (2014). Diabetes Fakta dan Angka Peraturan Menteri Kesehatan Nomor 5 Tahun 2014. Jakarta: Kementerian Kesehatan.

Yuda, P.G.A.A., Rusli, R., \& Ibrahim, A. (2015). Kandungan Metabolit Sekunder dan Efek Penurunan Kadar Glukosa Darah Ekstrak Biji Rambutan (Nephelium lappaceum pada Mencit (Mus musculus). Jurnal Sains dan Kesehatan, 1(3), 24076082. 